\title{
Sosialisasi dan Mitigasi Gempa Bumi Menggunakan Media Komik Edukasi Pada Panti Asuhan Dharma Jati I Klungkung Provinsi Bali
}

\author{
Nia Maharani*1 , Ni Putu Eka Kherismawati ${ }^{2}$, I Made Dedy Setiawan ${ }^{3}$ \\ ${ }^{123}$ STMIK STIKOM, Indonesia \\ E-mail*: maharani.nst@gmail.com
}

Article History:

Received: Agustus 2021

Revised: September 201

Accepted:Oktober 2021

Available online:

Desember 2021

\section{Keywords:}

Bencana gempa bumi, kesiapsiagaan, komik edukasi
Abstract: Banyaknya kejadian gempa bumi yang terjadi di Kabupaten Klungkung, Provinsi Bali membuat kesiapsiagaan masyarakat perlu ditingkatkan sehingga mampu meminimalisir jatuhnya korban. Kesiapsiagaan sebaiknya diberikan pada saat usia dini, anak-anak di bangku Sekolah Dasar sampai Sekolah Atas. Panti Asuhan Dharma Jati I merupakan salah satu panti asuhan yang terdapat di Kabupaten Klungkung, ikut merasakan gempa bumi yang terjadi pada tahun 2020. Berdasarkan observasi dan wawancara pada pengelola panti asuhan pada saat terjadinya gempa bumi anak-anak panti asuhan yang rata-rata berumur 8-14 tahun panik, bingung dan berlari keluar panti asuhan. Untuk itu tujuan pengabdian ini adalah untuk mengadakan sosialisasi gempa bumi dan mitigasinya pada panti asuhan Dharma Jati I menggunakan meda komik edukasi. Alasan menggunakan media komik karena keterbatasan sarana prasarana yag ada pada panti asuhan tersebut. metode pelaksanaan kegiatan ini terdiri dari dua tahap yaitu tahap awal pada tahap ini diberikan soalsoal pretest untuk melihat sejauh mana pengetahuan anak panti asuhan dan tahap kedua adalah tahap akhir yaitu sosialisasi gempa bumi dan mitigasinya lalu diadakan posttest. Hasil pretest dan posttest menunjukkan terdapat peningkatan 
pengetahuan anak-anak panti asuhan tentang gempa bumi dan mitigsinya sebesar $20-40 \%$. Hasil ini menunjukkan bahwa kegiatan sosialisasi menggunakan media komik edukasi memberikan dampak yang positif terhadap anak-anak panti asuhan.

\section{Pendahuluan}

Bencana merupakan peristiwa atau rangkaian peristiwa yang mengancam dan mengganggu kehidupan dan penghidupan masyarakat yang disebabkan baik oleh faktor alam dan/ faktor nonalam maupun faktor manusia sehingga mengakibatkan timbulnya korban jiwa manusia, kerusakan lingkungan, kerugian harta benda, dan dampak psikologis (Pribadi, 2008). Indonesia merupakan salah satu negara rawan yang akan bencana gempa bumi karena merupakan negara kepulauan yang diapit oleh tiga lempeng yaitu diantaranya lempeng Eurasia, lempeng Indo-Australia dan lempeng Pasifik. Akibat letak geografis inilah Indonesia merupakan negara yang memiliki potensi gempa bumi terbesar di dunia. Ketika terjadi gempa, anak-anaklah yang paling rentan terkena dampaknya.Bali merupakan salah satu pulau di Indonesia yang memiliki potensi gempa bumi. Gempa bumi tidak dapat diprediksi lokasi dan waktu terjadinya. Ada tiga sumber utama potensi gempa dan tsunami di Bali yaitu di bagian utara laut Bali, Kecamatan Seririt, Kabupaten Buleleng dan bagian selatan Bali (Nia Maharani \& Krisna, 2020). Beberapa gempa bumi yang tercatat di Bali yang getarannya juga dirasakan para penghuni panti asuhan Dharma Jati I dan masyarakat Kabupaten Klungkung baik gempa-gempa kecil maupun gempa sedang dan gempa besar.

Panti Asuhan Dharma Jati I merupakan panti asuhan yang terletak di Jalan Bakas, Banjarangkan, Bakas, Kecamatan Klungkung, Kabupaten Klungkung Provinsi Bali. Panti asuhan ini memiliki cabang di Denpasar yaitu Panti Asuhan Dharma Jati II dibawah naungan Yayasan Dharma Jati. Panti Asuhan Dharma Jati I menampung dan mendidik anak-anak terlantar. Di panti ini anak-anak dibekali dengan pendidikan formal oleh guru-guru pengajar bantuan pada sore hari. Latar pendidikan anak-anak panti dari SD sampai SMA, namun lebih banyak yang berlatar belakang SD. Kegiatan pada siang 
hari anak-anak panti dibekali keterampilan menjahit, seni tari, membuat bakso, atletik dan lain-lain. Pada panti asuhan hanya terdapat media elektronik televisi sebagai sumber informasi bagi anak-anak panti asuhan dengan jumlah yang sangat terbatas. Untuk media cetak sendiri sangat terbatas sehingga anakanak panti asuhan kurang mendapatkan informasi terutama yang berkaitan dengan pendidikan.

Berdasarkan wawancara langsung pada pengelola panti dan beberapa anak panti asuhan saat gempa terjadi mereka panik dan berhamburan keluar rumah panti dan kadang bingung apa yang harus dilakukan. Dari hasil observasi kepada pengelola panti asuhan dan beberapa anak panti asuhan bahwa sebelumnya belum pernah ada kegiatan sosialisasi gempa bumi dan antisipasinya. Sehingga mereka belum memiliki pengetahuan dasar mengenai gempa bumi dan antisipasinya. Padahal pengetahuan gempa ini sangat penting untuk meminimalisir jumlah korban dan kerusakan akibat gempa bumi. Gempa terbaru yang dirasakan adalah gempa yang terjadi di Klungkung pada pukul 9.42 WITA dengan magnitude 4,2 SR. Pusat gempa terjadi di laut 57 barat daya Kuta Selatan. BMKG memperingati untuk waspada gempa susulan meski tidak ada korban dan kerusakan yang parah (N Maharani, 2021). Kemudian masih pada pusat yang sama tanggal 16 Juli 2019 gempa kembali terjadi dengan magnitudo 5.8. BMKG mencatat sebanyak 14 kali gempa susulan dengan magnitudo 2.4 hingga 3.5 (ITB, 2003). Gempa ini merupakan bagian dari rangkaian gempa bumi Bali akibat aktivitas subduksi lempeng Indo-Australia (Pribadi, 2008). Pada tahun 2018 pukul 01.23 WITA gempa bumi juga mengguncang kabupaten Klungkung dengan kekuatan 5,3 SR. Getarannya pun terasa sampai Lombok dan Nusa Tenggara (N Maharani, 2021). Dari kejadian-kejadian diatas tersebut maka sudah sepantasnya melalui pendidikan usia dini diharapkan agar upaya pengurangan resiko bencana dapat mencapai sasaran yang lebih luas dapat dikenalkan secara lebih dini kepada seluruh anak panti asuhan (N Maharani, 2021). Banyaknya korban jiwa dan kerugian material yang diakibatkan karena rendahnya tingkat kesiapsiagaan dan minimnya pengetahuan tentang gempa bumi itu (Nia Maharani, 2020).

Dari permasalahan yang telah dipaparkan pada sub bab sebelumnya maka tim PKM bermaksud mengadakan sosialisasi mengenai gempa bumi dan 
langkah-langkah yang harus ditempuh sebelum, saat dan setelah terjadi gempa pada anak-anak panti asuhan Dharma Jati I. Dengan keterbatasan sarana dan prasarana yang ada di panti asuhan, tim PKM memutuskan untuk menggunakan komik edukasi sebagai media penyampaian materi gempa bumi agar lebih menarik dan tidak membosankan. Dengan demikian diharapkan informasi dapat terserap dengan baik oleh anak-anak panti asuhan.

Kegiatan PKM SSE ini adalah untuk memberikan pengetahuan dasar mengenai gempa bumi dan mitigasinya kepada para anak panti asuhan sehingga apabila gempa bumi terjadi anak-panti asuhan bisa mengambil langkah - langkah guna meminimalisir korban bencana akibat gempa bumi itu sendiri. Penggunaan media komik edukasi gempa bumi bertujuan agar bisa diserap dengan baik dengan isi komik yang dibuat menggunakan bahasa yang sederhana dan dengan warna - warna menarik.Hal ini diinjau karena anakanak panti asuhan lebih banyak memiliki latar belakang pendidikan sekolah dasar.

\section{Metode}

Pelaksanaan PKM SSE dibagi menjadi dua tahapan yaitu Tahap Awal yang dilaksanakan pada tanggal 18 Mei 2021. Pada kegiatan ini tim PKM SSE mengunjungi panti asuhan Dharma Jati I Klungkung untuk pengambilan data awal atau pre-test. Pada tahapan ini anak-anak pati asuhan diberikan 10 pertanyaan dasar yang berkaitan dengan gempa bumi serta mitgasinya dalam benuk kuisioner lalu mereka menjawab. Tujuan pre -test ini adalah untuk melihat sejauh mana pengetahuan anak-anak panti asuhan tentang gempa bumi atau mencocokkan hasil wawancara dengan kondisi lapangan saat in (Siregar, 2013). Pada saat wawancara langsung kepada anak-anak panti asuhan menyatakan bahwa belum pernah ada kegiatan sosialisasi tentang gempa bumi di panti asuhan selama ini termasuk menggunakan media komik edukasi. Selama ini mereka mendapatkan pengetahuan gempa hanya dari penjelasan guru di sekolah untuk anak-anak panti asuhan yang berlatar belakang pendidikan SMP. Untuk yang duduk di jenjang sekolah dasar belum pernah mendapatkan penjelasan tentang gempa bumi dan mitigasinya. Pada tahap awal ini juga sudah dirancang komik edukasi gempa bumi untuk 
digunakan saat sosialisasi gempa bumi pada tahaan akhir karena berdasarkan analisis situasi dan permasalahan mitra bahwa informasi yang mereka peroleh sangat minim karena keterbatasan sarana prasarana panti seperti televisi, gadget dan media cetak.

Tahap Akhir dilaksanakan pada tanggal 11 Juli 2021. Pada kunjungan kedua ini tim PKM SSE mengadakan sosilasisasi mengenai gempa bumi dan mitigasinya menggunakan komik edukasi yang sudah dicetak dan diberikan secara langsung kepada anak-anak panti asuhan. Setelah sosiaslisasi selesai maka anak-anak panti asuhan diberikan tes akhir atau post-test yaitu dengan memberikan 10 pertanyaan dasar yang sama seperti tahapan awal untuk melihat sejauh mana pengetahuan anak-anak panti asuhan setelah diadakan penyuluhan menggunakan komik edukasi yang dipaparkan oleh tim PKM SSE. Hasil ini sebagai bentuk evaluasi apakah kegiatan ini memberikan dampak kepada anak-anak panti asuhan atau tidak.

\section{Hasil}

Data yang digunakan pada tahap awal PKM ini adalah data primer yang diambil langsung dari 25 anak panti asuhan menggunakan kuisioner sebagai pretest. Data diambil dan dikumpulkan pada tanggal 18 Mei 2021 di Panti Asuhan Dharma Jati I Klungkung lalu dianalisis menggunakan teknik analisis univariat dengan statistik sederhana (Sugiono, 2015). Data kuisioner berisi 10 pertanyaan dasar untuk melihat sejauh mana pengetahuan responden tentang gempa bumi. Hasil kuisioner adalah sebagai berikut, pada pertanyaan pertama tentang apa yang dimaksud dengan bencana alam, didapatkan sebanyak $80 \%$ anak panti asuhan menjawab benar dan $20 \%$ menjawab salah, dari hasil tersebut dapat disimpulkan bahwa anak-anak panti asuhan sudah memiliki pengetahuan yang baik tentang definisi bencana. Ini sudah langkah awal yang baik karena bencana dapat terjadi dimanapun dan kapanpun tidak dapat diprediksi (Ardiansyah, 2017). Pada pertanyaan kedua mengenai fenomena yang dapat dinyatakan suatu keadaan tersebut adalah gempa bumi didapatkan sebanyak $60 \%$ anak panti asuhan menjawab benar dan $40 \%$ menjawab salah. Untuk pertanyaan ini juga anak-anak panti asuhan sudah menjawab dengan baik. Berdasarkan wawancara singkat kepada anak panti asuhan, pengertian gempa bumi pernah mereka dapatkan di bangku sekolah 
SMP dan SMA saat pelajaran IPS. Ini juga merupakan langkah awal yang baik karena sekolah merupakan salah satu tempat untuk mendapatkan informasi tentang gempa bumi yang paling tepat untuk anak-anak usia dini.

Pada pertanyaan ketiga mengenai pendapat tentang penyebab terjadinya gempa bumi, sebanyak $40 \%$ anak panti asuhan menjawab benar dan $60 \%$ menjawab salah, dari hasil ini terlihat bahwa pengetahuan anak-anak panti asuhan masih kurang, sedangkan pada pertanyaan keempat yaitu mengenai yang dilakukan jika seandainya terjadi gempa bumi dan posisi sedang berada digedung bertingkat didapatkan sebanyak $60 \%$ anak panti asuhan menjawab benar dan $40 \%$ menjawab salah. Hasil ini juga menunjukkan masih kurangnya pengetahuan anak panti asuhan tentang mitigasi gempa bumi saat di gedung bertingkat. Hal yang mempengaruhi respon terhadap bencana adalah sikap, pengetahuan dan partisipasi. Saat menghadapi bencana diperlukan ketenangan dan sikap tidak mudah panik. Kondisi kognitif dan penanggulangan bencana baik berpengaruh pada tindakan fisik dan psikologis (Pasau, 2007).

Pada pertanyaan kelima mengenai jenis bangunan yang dinilai paling aman untuk daerah rawan gempa, didapatkan sebanyak $40 \%$ anak panti asuhan menjawab benar dan $60 \%$ menjawab salah, dari hasil tersebut masih kuangnya pengetahuan anak panti asuhan mengenai mateial bangunan yang tahan akan gempa bumi. Sedangkan pada pertanyaan keenam yaitu mengenai yang dilakukan jika seandainya terjadi gempa bumi dan posisi sedang berada dilift didapatkan sebanyak $20 \%$ anak panti asuhan menjawab benar dan $80 \%$ menjawab salah. Hal ini menunjukkan masih belum mapannya informasi mitigasi saat gempa bumi posisi berada dilift.

Dilanjutkan ke pertanyaan ketujuh mengenai yang dilakukan jika seandainya terjadi gempa bumi dan posisi sedang berada diluar ruangan, didapatkan sebanyak $56 \%$ anak panti asuhan menjawab benar dan $44 \%$ menjawab salah, hasil ini sudah cukup baik sedangkan pada pertanyaan kedelapan yaitu mengenai yang dilakukan jika seandainya terjadi gempa bumi dan posisi sedang berada didalam kendaraan didapatkan sebanyak $32 \%$ anak panti asuhan menjawab benar dan $68 \%$ anak panti asuhan menjawab salah. Pengetahuan anak panti untuk mitigasi gempa masih kurang karena anak panti 
asuhan sebagian besar belum merasakan gempa bumi saat di dalam mobil, pengalaman yang pernah didapat juga menjadi poin penting untuk mitigasi (Overton, 2014).

Pada pertanyaan kesembilan mengenai yang dilakukan jika seandainya terjadi gempa bumi dan posisi sedang berada dilantai dasar, didapatkan sebanyak 52\% anak panti asuhan menjawab benar dan $48 \%$ menjawab salah, hasil ini juga didukung karena panti asuhan Dharma Jati I merupakan bangunan lantai satu, sehingga penegetahuan mitigasi anak panti cukup baik. Pada pertanyaan kesepuluh yaitu mengenai potensi risiko yang terdapat dilingkungan sekolah jika terjadi gempa bumi didapatkan sebanyak $80 \%$ anak panti asuhan menjawab benar dan 20\% menjawab salah. Hal ini dipengaruhi oleh pengalaman dan pengetahuan yang sangat baik, yang diperoleh di sekolah tentang kesiapsiagaan saat terjadi gempa bumi di sekolah (Ardiansyah, 2017).

Pada hasil pertanyaan kuisioner tentang ada atau tidaknya penyuluhan gempa sebelum saat dan sesudah terjadi gempa didapatkan sebanyak $100 \%$ dari anak panti asuhan menjawab belum mendapat penyuluhan tentang gempa bumi bisa menggunakan media cetak maupun media IT. Informasi yang diperoleh anak panti asuhan hanya sebatas pengertian dasar bencana dan gempa bumi belum sampai sampai tahap detil mitigasi.Pada tanggal 11 Juli 2021 dilakukan kunjungan kedua yang bertujuan untuk melakukan penyuluhan gempa bumi dan mitigasinya kepada anak-anak panti asuhan dengan komik edukasi gempa bumi. Komik yang disusun sedemikian rupa dengan kalimat-kalimat sederhana, ringkas serta gambar-gambar menarik yang penuh warna sehingga tampilan isi komik jadi lebih menarik seperti pada gambar 1.

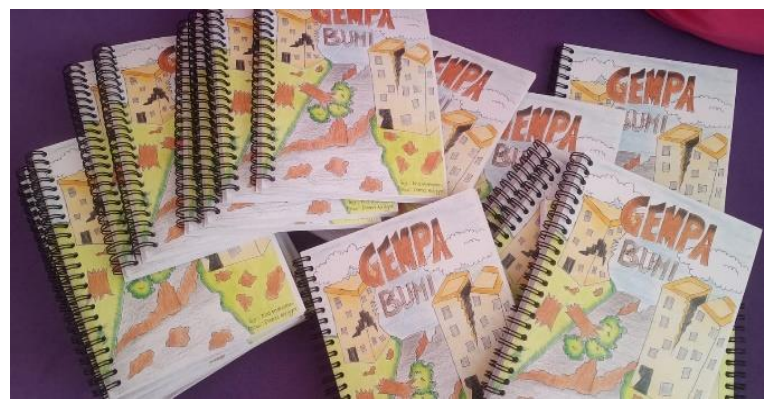

Gambar 1. Komik Edukasi 
Tokoh-tokoh dalam cerita komik diantaranya Lia, Nayla, Ayah dan Bunda. Penggunaan media komik edukasi ini karena masih terabatasnya sarana dan prasarana yang ada di panti asuhan. Ketersiadaan media komunikasi cetak dan elektronik di panti asuhan menjadi alasan mengapa kegiatan penyuluhan ini menggunakan komik edukasi. Alasan lainnya juga karena $97 \%$ anak - anak panti asuhan berlatar pendidikan sekolah dasar dan sisanya berlatar pendidikan sekolah menengah pertama.

Penggunaan komik edukasi ini diharapkan kegiatan penyuluhan jadi lebih menarik dengan gaya bercerita isi komik dipaparkan oleh tim PKM SSE secara bergantian dan diikuti dengan serius serta tertib oleh anak-anak panti asuhan seperti pada gambar 2 berikut.

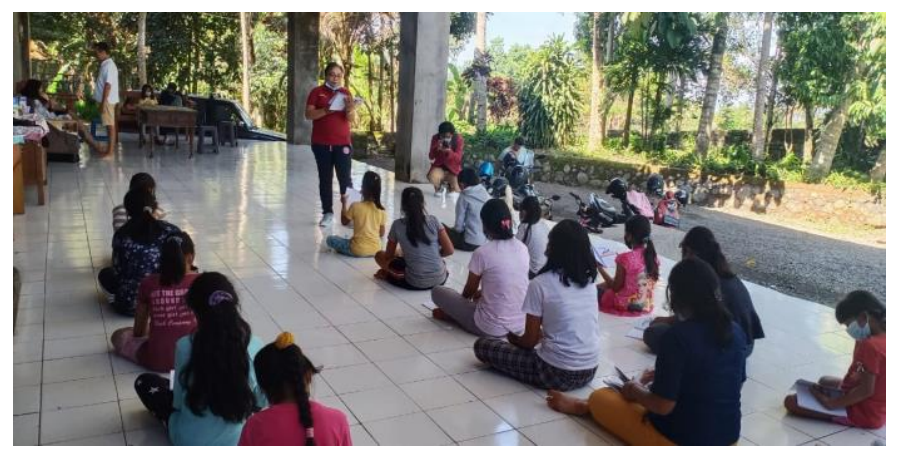

Gambar2. Penyuluhan Gempa Bumi Komik Edukasi

Setelah pemaparan selesai dilanjutkan dengan sesi tanya jawab mengenai gempa bumi dan mitigasinya. Setelah kegiatan sesi tanya jawab, dilanjutkan dengan kegiatan evaluasi akhir atau post - test melalui kuisioner berisi 10 pertanyaan sama seperti kuisioner pre - test. Dari hasil tes awal dapat disimpulkan bahwa anak-anak panti asuhan belum memahami mitigasi gempa bumi saat situasi kondisi tertentu dan belum ada penyuluhan gempa bumi pada panti asuhan tersebut. Jadi dengan hasil tersebut memperkuat alasan tim PKM SSE untuk mengadakan penyuluhan gempa bumi setelah sebelumnya mengadakan wawancara langsung dengan pengelola panti asuhan dan anak anak panti asuhan dan menyesuaikan dengan kondisi lapangan ternyata cocok. Dari hasil evaluasi akhir diperoleh adanya peningkatan presentase memilih 
jawaban yang benar. Untuk soal kuisioner pertama yang menanyakan pengertian bencana alam, $100 \%$ menjawab benar sebelumya saat tes awal hanya $80 \%$ menjawab benar dan sisanya salah. Ada peningkatan presentase menjawab benar sebanyak $20 \%$. Untuk soal kuisioner kedua tentang fenomena yang dapat diketahui untuk menyatakan suatu keadaan tersebut adalah gempa bumi, saat tes awal hanya $60 \%$ yang menjawab benar, $40 \%$ menjawab salah. Saat tes akhir diperoleh $90 \%$ menjawab benar serta sisanya menjawab salah. Dari hasil kedua pertanyaan kuisioner tes akhir ini ternyata memberikan dampak yang positif yaitu pengetahuan anak-anak panti asuhan mengalami peningkatan setelah dilakukan sosialisasi menggunakan media komik edukasi. Pertanyaan ketiga kuisioner tentang penyebab terjadi gempa bumi, sebanyak $85 \%$ responden menjawab dengan benar, $15 \%$ menjawab salah. Untuk pertanyaan ketiga ini juga mengalami peningkatan setelah sebelumnya hanya $40 \%$ anak - anak panti asuhan menjawab benar dan $60 \%$ menjawab salah.

Kuisioner keempat berisi petanyaan mitigasi saat gempa bumi tejadi dan posisi responden sedang berada dalam gedung bertingkat. Hasil yang diperoleh saat tes awal hanya $60 \%$ menjawab benar dan $40 \%$ menjawab salah sedangkan setelah dilakukan penyuluhan presentase responden yang menjawab benar meningkat menjadi $90 \%$ menjawab benar dan $10 \%$ menjawab salah. Untuk pertanyaan mengenai jenis bahan apa yang dinilai paling aman untuk daerah rawan gempa pada pertanyaan kelima kuisioner, $100 \%$ responden menjawab benar saat tes akhir sedangkan saat tes awal hanya $40 \%$ menjawab benar. Untuk pertanyaan kuisioner keenam tentang mitigasi saat responden berada di lift, saat tes awal hanya $20 \%$ menjawab benar karena responden sangat jarang menggunakan lift, jadi hasil ini sesuai dengan kondisi lapangan. Namun setelah dilakukan penyuluhan demgan komik edukasi responden yang menjawab benar meningkat menjadi $80 \%$, karena pada komik dijelaskan mengenai mitigasi kondisi tersebut. Anak- anak panti asuhan dapat menyerap dengan baik informasi yang disampaikan oleh tim PKM SSE. Pertanyaan kuisioner ketujuh beisi tentang mitigasi saat posisi sedang berada diluar ruangan, $90 \%$ responden menjawab dengan benar dan $10 \%$ menjawab 
salah. Ada peningkatan presentase menjawab benar sebelum dan setelah sosialisasi.

Mitigasi saat responden berada dalam kendaraan dipaparkan pada pertanyaan kuisioner kedelapan dengan hasil $87 \%$ responden menjawab benar dan $13 \%$ menjawab salah. Bila dibandingkan dengan tes awal juga mengalami peningkatan yang cukup signifikan untuk responden yang menjawab benar. Kuisioner kesembilan berisi pertanyaan mitigasi saat di lantai dasar terjadi gempa bumi dengan hasil semua responden menjawab dengan benar karena untuk kondisi seperti ini mereka pernah mengalami. Kuisioner kesepuluh berisi pertanyaan tentang potensi resiko yang terdapat di lingkungan sekolah saat terjadi gempa dengan hasil semua responden menjawab benar yaitu potensi resiko yang berasal dari runtuhan bangunan, pecahan kaca dan kebakaran. Setelah dilakukan posttest melalui pemberian kuisioner ini, maka kegiatan terakhir ditutup dengan sesi foto bersama antara tim PKM SSE dengan anak-anak Panti Asuhan Dharma Jati I Klungkung seperti pada gambar 3 berikut.

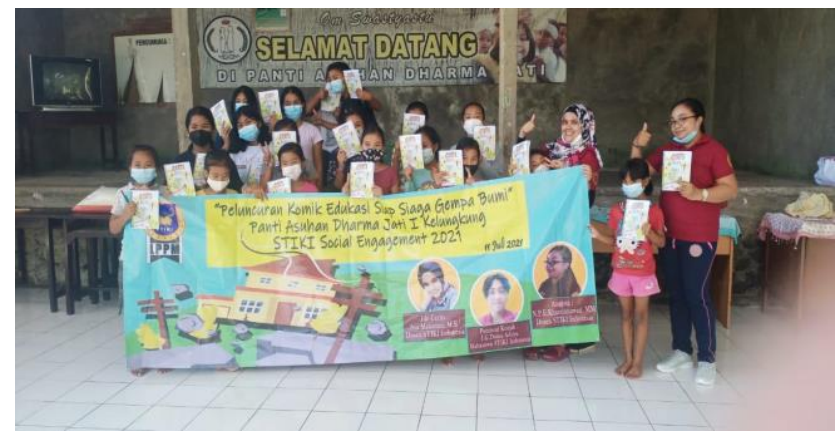

Gambar 3. Tim PKM bersama anak-anak Panti Asuhan Dharma Jati

\section{Kesimpulan}

Dari kegiatan PKM ini dapat diambil beberapa kesimpulan yaitu 1) Dari hasil kuisioner tes awal dan tes akhir yang diberikan pada kegiatan PKM SSE ini terdapat peningkatan pengetahuan anak-anak panti asuhan sebesar 2040\%. Hasil ini menunjukkan bahwa kegiatan PKM SSE ini memberikan dampak yang positif terhadap anak-anak panti asuhan. Mereka jadi lebih mengetahui tentang gempa bumi dan mitigasinya, sehingga saat terjadi gempa bumi mereka tidak lagi bingung, 2) Salah satu faktor peningkatan pengetahuan 
mengenai gempa bumi dan mitigasinya karena media yang digunakan dalam penyuluhan adalah komik edukasi. Komik edukasi yang dibuat secara manual dengan konsep cerita yang sederhana serta dengan warna-warna yang menarik membuat anak-anak panti asuhan lebih cepat memahami karena dirasa menarik dan tidak membosankan karena penyuluhan disajikan dalam bentuk cerita yang disampaikan dalam bentuk cerita sehingga ada ciri khas tersendiri.

\section{Pengakuan/Acknowledgements}

Terima kasih yang sebesar-besarnya kepada semua pihak yang telah membantu, memberikan dukungan, dan terlibat dalam penelitian ini, harapan kami semoga penelitian yang telah peneliti hasilkan dapat bermanfaat dan dapat lebih disempurnakan di masa yang akan datang. Artikel ini merupakan publikasi hasil pengabdian masyarakat dengan skema STIKI Social Engagement (SSE) 2021 dengan menggunakan dana yang bersumber dari LPPM STMIK STIKOM Indonesia dengan nomor kontrak penelitian SSE 57/04/LPPM/PKM.SSE/IV/2021. Oleh karena itu, penulis mengucapkan terima kasih kepada LPPM STMIK STIKOM Indonesia atas dukungan material maupun nonmaterial yang telah diberikan.

\section{Daftar Referensi}

Ardiansyah, A. D. (2017). SMAN Muhammadiyah Toboali 121. Jurnal Pendidikan Geografi: Pendidikan Dan Ilmu Geografi, 22(2), 121-134. Retrieved from http://journal2.um.ac.id/index.php/jpg/

ITB, K. M. B. (2003). Program Kesiapan Sekolah Terhadap Bahaya Gempa Bumi. Jakarta: Ditejen Mandikdasmen Depdik.

Maharani, N. (2020). Tingkat Pengetahuan Siswa Tentang Kesiapsiagaan Bencana Gempa Bumi Di SMPN 3 Kuta Selatan Badung Provinsi Bali. PENDIPA Journal of Science Education, 4(3), 32-38. https://doi.org/10.33369/pendipa.4.3.32-38

Maharani, N. (2021). Sosialisasi Dan Mitigasi Gempa Bumi Menggunakan Media Berbasis Virtual Reality Pada Panti Asuhan Adzkiyah Alkhair Kecamatan (JBS): Media Publikasi Penelitian Dan 10(01), 52-58. Retrieved from http://ejournal.unmas.ac.id/index.php/baktisaraswati/article/view/2094

Maharani, N., \& Krisna, E. D. (2020). Sosialisasi Mitigasi dan Game Gempa Bumi Pada Panti Asuhan Dharma Jati Kecamatan Denpasar Timur Provinsi Bali. Dharma Raflesia : Jurnal Ilmiah Pengembangan Dan Penerapan IPTEKS, 18(2), 133-141. https://doi.org/10.33369/dr.v18i2.13213 
Overton, L. R.-A. (2014). From Vulnerability to Resilience: an Exploration of Gender Performance Art and how it has Enabled Young women's Empowerment in Post-hurricane new Orleans. Procedia Economics and Finance, 18(July), 214221. https://doi.org/10.1016/s2212-5671(14)00933-2

Pasau, G. (2007). Respons Spektra Gempa Bumi Di Batuan Dasar Kota Bitung Sulawesi Utara Pada Periode Ulang 2500 Tahun the Response of Spectral Earthquake on the Bedrock of Bitung City North Sulawesi During 2500-YearReturn Period. 1-6.

Pribadi. (2008). Buku Pegangan Guru : Pendidikan Siaga Bencana.

Siregar, S. (2013). Metode Penelitian Kuantitatif: Dilengkapi Perbandingan Perhitungan Manual dan SPSS. Jakarta: Kencana Prenada Media Group.

Sugiono. (2015). Metode Penelitian Pendidikan Pendekatan Kuantitatif, Kualitatif, dan R\&D. Bandung: Alfabeta. 